\title{
Characterization of the spoilage potential of pure and mixed cultures of bacterial species isolated from tropical yellowfin tuna (Thunnus albacares)
}

\author{
Silbande Adèle ${ }^{1,2,3}$, Cornet Josiane ${ }^{1}$, Cardinal Mireille ${ }^{1}$, Chevalier Frederique ${ }^{1}$, Rochefort Katia ${ }^{2}$, \\ Smith-Ravin Juliette ${ }^{3}$, Adenet S. ${ }^{2}$, Leroi Françoise ${ }^{1,}$
}

${ }^{1}$ Ifremer, Laboratoire Ecosystèmes Microbiens et Molécules Marines pour les Biotechnologies (EM B), rue de l'lle d'Yeu; BP 2110544300 Nantes ,France

2 Pôle Agroalimentaire Régional de Martinique (PARM), impasse Petit-Morne; N 37597232 Lamentin, Martinique

${ }^{3}$ Université des Antilles, Département Scientifique Inter facultaire (DSI), EA929 AIHP-GEODE (groupe

BIOSPHERES); BP 720997275 Schoelcher ,Martinique

* Corresponding author : Françoise Leroi, email address : fleroi@ifremer.fr

\begin{abstract}
:
Aim

The spoilage potential of 28 bacterial strains isolated from spoiled raw yellowfin tuna was evaluated.

Methods and Results

Bacterial species were inoculated in irradiated tuna matrix. Chemical changes, bacterial growth and sensory quality were monitored during aerobic storage at $8^{\circ} \mathrm{C}$. Pseudomonas spp., Enterobacter spp. and Escherichia hermanii had no spoiling effect. Brochothrix thermosphacta and Carnobacterium divergens/maltaromaticum developed moderate unpleasant odors. Hafnia paralvei and Serratia spp. released strong off-odors (pyrrolidine, sulfur/cabbage). No bacterial group (except $H$. paralvei) combined with Pseudomonas spp. deteriorated the sensory quality of tuna. When $C$. divergens/maltaromaticum was associated with $H$. paralvei or $B$. thermosphacta, the odor is close to the naturally contaminated tuna stored on the same conditions. The $\mathrm{pH}$, Total Volatile Basic Nitrogen (TVBN) and Trimethylamine (TMA) were not correlated with the spoilage.
\end{abstract}

Conclusions

The bacterial species had a different impact on the sensory quality of the fish. The bacterial interactions leading to an enhancement or an inhibition of the spoilage potential and the bacterial growth. 
Significance and Impact of Study

The Specific Spoilage Organism (SSO) appears to be an association of Lactic Acid Bacteria (LAB) with Enterobacteriaceae or $B$. thermosphacta. Pseudomonas, often dominant at the sensory rejection time, is not a good quality indicator.

Keywords: Tuna, Spoilage potential, Bacterial species, Sensory quality, Bacterial interaction, Pseudomonas, Fish, Tropical 


\section{Introduction}

World catches of tuna and tuna-like species was multiplied by 10 since 1950 and represent more than 7.5 millions of tons in 2014. The yellowfin tuna (Thunnus albacares), predominant in tropical and subtropical waters, corresponds to $20 \%$ of this production value (FAO, 2016). The flesh is increasingly consumed raw such as sashimi and sushi. Fresh fish meat is an ideal substrate for the bacterial growth which is mainly responsible for the sensory deterioration (Gram and Huss, 1996, 2000; Leroi and Joffraud, 2011). Most of the studies of the microbiota of raw yellowfin tuna focuses on the histamine-producing bacteria potentially responsible for the human histamine-fish-poisoning illness (Du et al., 2002; Emborg et al., 2005; Guizani et al., 2005; Ferrario et al., 2012; Sika et al., 2014). More recently, Silbande et al. (2016) monitored the quantitative and qualitative composition of the microbial ecosystem present in raw tuna steaks under different conditions of storage. At the sensory rejection time, Brochothrix thermosphacta and Pseudomonas spp. dominated the microbiota of products stored in air at $0^{\circ} \mathrm{C}$ while $B$. thermosphacta alone or a mix of $B$. thermosphacta, Enterobacteriaceae and lactic acid bacteria 
(LAB) prevailed in modified atmosphere-packed (MAP) and vacuum-packed (VP) products, respectively. Gram-negative bacteria such as Pseudomonas are wellknown as predominant microorganism during chilled storage of fish in presence of $\mathrm{O}_{2}$ (Ghaly et al., 2010) while the anaero-aerotolerant LAB are more frequently isolated from VP and MAP fish, as well as lightly preserved seafood (Franzetti et al., 2003; Leroi, 2010). B. thermosphacta and enteric bacteria have also been reported in $\mathrm{CO}_{2} / \mathrm{O}_{2}$ or $\mathrm{CO}_{2} / \mathrm{N}_{2}$ atmosphere and VP products (González-Rodríguez et al., 2002; Emborg et al., 2005; Hovda et al., 2006; Olofsson et al., 2007; Chaillou et al., 2015; Parlapani et al., 2015b). However, many of the bacterial species present at the sensory rejection time do not contribute to the sensory degradation of products and it is therefore important to identify the specific spoilage organisms (SSO) (Gram and Dalgaard, 2002). Depending on the SSO, it is generally admitted that the count should reach 8-9 $\mathrm{Log} \mathrm{CFU} \mathrm{g}^{-1}$ to observe the deterioration of fresh or processed cold-water fish (Leroi et al., 2001). However, Du et al. (2001) and Silbande et al. (2016) reported that the organoleptic quality of raw yellowfin tuna steaks stored in air, VP and MAP was unacceptable at 6-7 Log CFU g ${ }^{-1}$. The spoiling effects were characterized by slime formation, putrefactive odor and loss of the typical red color whose development is faster when storage temperature increases. The growth of spoiling bacteria and their sensory impact depend on the food matrix and the storage conditions but also on the interaction with other bacterial species (Joffraud et al., 2006; Laursen et al., 2006; Alfaro et al., 2013). Identifying the SSO and understanding the mechanism involved in the spoilage of raw yellowfin tuna is important to predict shelf-life of products and develop preservative techniques. The present study investigates the spoilage potential of several bacterial species previously isolated from tropical yellowfin tuna steaks (Silbande et al., 2016). The 
ability of each isolate to produce unpleasant odors or color was assessed in irradiated yellowfin tuna flesh, both in pure and mixed culture.

\section{Materials and Methods}

\section{Isolation, purification and identification of bacterial strains}

Twenty-eight strains of Brochothrix, Pseudomonas, Carnobacterium, Hafnia, Serratia, Enterobacter and Escherichia were previously isolated from yellowfin tuna steaks stored in air at $0^{\circ} \mathrm{C}$ or VP and MAP $\left(70 \% \mathrm{CO}_{2}-30 \% \mathrm{O}_{2}\right)$ at $4 / 8^{\circ} \mathrm{C}$, at the sensory rejection time (13 days) (Silbande et al., 2016). Isolates were purified twice on Brain Heart Infusion agar (BHI, Biokar Diagnostic, Beauvais, France) with 2\% $\mathrm{NaCl}$ and maintained as frozen stocks at $-80^{\circ} \mathrm{C}$ in a cryoprotector medium $(\mathrm{BHI}$ with $2 \% \mathrm{NaCl}$ and $20 \%$ of glycerol). Strains have been identified by total $16 \mathrm{~S}$ rDNA sequences analysis (1500 bp) as described by Macé et al. (2012). They are presented in Table 1.

\section{Preparation of the pauci-microbial tuna matrix}

Whole and gutted tunas, freshly caught off the coast of Martinique, were transported directly to the PARM laboratory. All the flesh $(6 \mathrm{~kg})$ was cut into approximately $2 \mathrm{~cm}^{3}$ cubes with the greatest hygienic precautions $\left(12^{\circ} \mathrm{C}\right.$-room, disinfection of material and equipment). These pieces were vacuum-packed in $500 \mathrm{~g}$ plastic bags, frozen at $-80^{\circ} \mathrm{C}$ and irradiated between 5.9 to $6.6 \mathrm{KGy}$ in a plant equipped with cobalt 60 source electron beam facilities (Ionisos, Pouzauges, France). The matrix was kept at $-80^{\circ} \mathrm{C}$. Before beginning the experiment, diced tuna was thawed in ambient water bath for 30 to $45 \mathrm{~min}$ and divided in several 30,100 and $150 \mathrm{~g}$ portions in 
polyamide/polyethylene bags (oxygen transmission rate of $40-50 \mathrm{~cm}^{3} / \mathrm{m}^{2} / 24 \mathrm{~h} / \mathrm{atm}$ at $23^{\circ} \mathrm{C}$ and $75 \% \mathrm{RH}$ and $\mathrm{CO}_{2}$ transmission rate of $\left.146 \mathrm{~cm}^{3} / \mathrm{m}^{2} / 24 \mathrm{~h} / \mathrm{atm}\right)$.

\section{Challenge test: strain culture, sample inoculation and packaging}

In the first trial of experiments, each species (mix of strains from the same species) or each genus (mix of strains from the same genus) were tested separately. In total, 9 groups of 2 to 4 strains were tested (Table 1). Each bacterial strain was pre-cultured individually in $10 \mathrm{ml}$ of $\mathrm{BHI}$ with $2 \% \mathrm{NaCl}$ at $20^{\circ} \mathrm{C}$. After 24 to $48 \mathrm{~h}, 100$ $\mu \mathrm{l}$ of the pre-culture was transferred into $10 \mathrm{ml}$ of saline $\mathrm{BHI}$ and placed at $20^{\circ} \mathrm{C}$ until an absorbance-estimated concentration level of approximately 9 Log CFU ml-1. The different strains of each group were mixed in equal proportions (final volume of 10 $\mathrm{ml}$ ). Two successive dilutions (2-fold and 100-fold) of each group were carried out in tryptone-salt broth (Biokar Diagnostic, Beauvais, France). Volume of 0.6, 2 and $3 \mathrm{ml}$ was directly incorporated in each of the 30,100 and $150 \mathrm{~g}$ tuna portion, respectively, to achieve a final concentration in the flesh of approximately $5 \mathrm{Log} \mathrm{CFU} \mathrm{g}^{-1}$ with an inoculation rate of $2 \%(\mathrm{v} / \mathrm{w})$. These samples were mixed manually during 2 minutes. Similar portions of non-inoculated flesh (control) were also prepared. All the samples were stored aerobically at $8^{\circ} \mathrm{C}$ in vertical position. Sensory, microbiological and chemical analyses were carried out immediately after inoculation (day 0) and at day $3,6,9,13$ and 17 . For sensory analysis, samples were placed at $-80^{\circ} \mathrm{C}$ until the test. Similarly, a second trial consisted to combine by pair some of the nine groups. A combination of 4 groups was also prepared. In total, 11 combinations and an uninoculated control, presented in Table 1, were prepared as previously described and analyzed at day $0,6,13$ and 17 . 


\section{Sensory analysis}

Before starting the experiment, a discussion was organized with 17 trained panellists of Ifremer to choose the relevant sensory descriptors, on the basis of the evaluation of non-irradiated and irradiated tuna after 0 and 9 days of storage at $8^{\circ} \mathrm{C}$. For the single-group characterization, 12 panellists from the preliminary evaluation carried out the sensory analysis to determine the influence of the bacterial species on tuna spoilage. At each sampling date, session was performed in individual testing booths according to the procedure NF V 09-105 (AFNOR, 1995), equipped with a computerized system (Fizz, Biosystèmes, Couternon, France). One packet per batch (150 g) was thawed, divided in individual portions (20-25 g), placed in plastic bowls with lids and maintained in an oven at $18^{\circ} \mathrm{C}$ during the session. All products were coded with random 3-digit numbers and served to the panellists in a predefined order to avoid a bias due to the effect of the first group tested. The set of 10 samples ( 9 inoculated and 1 control) was scored by 2 different panellists with a minimum of 20 min interval. This allow minimizing the total quantity of tuna flesh for sensory analysis. A control (irradiated tuna at day 0 ), thawed morning of the test, was proposed at each session as a reference. At each session, panellists had to score an overall spoilage level based on odor on a continuous scale from 0 to 10 (6 was determined as the limit of acceptability) and then the following appropriate odor descriptors: marine/fish, vegetal, grilled, floor cloth, butter/caramel, acid, sour/fermented, pyrrolidine, feet/cheese, amine, sulfur/cabbage. Moreover, panellists had to evaluate the color intensity on a 10-point scale ranging from red/pink (0) to beige (10). In the second trial, the same procedure was repeated for the characterization of the different bacterial combinations, with minor differences: the panel was composed of 14 judges from the preliminary discussion, the set presented 
to panellists consisted of 12 samples (11 inoculated and 1 control) and 2 descriptors (rancid and fecal), often cited by panellists during the first test, were added to the list. Data of each sensory spoilage level and descriptor were submitted to two-way analysis of variance (ANOVA) with products and panellists as independent factors to identify significant product effects. Principal component analysis (PCA) and ascending hierarchical clustering $(\mathrm{AHC})$ with standardization were realized for the odor profile of groups and combinations, respectively. The statistical treatments were carried out with Fizz 2.50 b 37 software (Biosystèmes), except the AHC which was performed with R software (3.2.1. version).

\section{Enumeration of the bacterial groups}

At each sampling date, one packet $(30 \mathrm{~g})$ of each group or combination was used for microbial analysis. The fish flesh was aseptically added to $120 \mathrm{ml}$ of sterile tryptone-salt broth (Biokar Diagnostic) and stomached for 2 min with a stomacher 400 (Seward Ltd., London, UK) to obtain the mother solution. Depending on the potential development of the bacterial groups at each sampling date, one to seven 10-fold dilutions were carried out in tryptone-salt solution. For the 9 individual bacterial groups and controls, the total viable count (TVC) was enumerated by spread plating onto Long and Hammer with $1 \% \mathrm{NaCl}$ plates (Van Spreekens, 1974) incubated 5 days at $20^{\circ} \mathrm{C}$. For the 11 bacterial combinations, selective culture media were used to distinguish the different genus of bacteria. Brochothrix sp. (Bx),

Pseudomonas sp. (Ps.) and Carnobacterium sp. (Ca) were enumerated by spreading $100 \mu \mathrm{l}$ of diluted mother solution onto respective plates of Streptomycin Thallium Acetate Agar (Oxoid, Basingstoke, Hampshire, England) (2 days at $20^{\circ} \mathrm{C}$ ), supplemented Cetrimide Fucidin Cephalosporin agar (Biokar Diagnostic) (2 days at 
$20^{\circ} \mathrm{C}$ ) and Nitrite Actidione Polymixin agar as prepared by Davidson and Cronin (1973) (3 days at $20^{\circ} \mathrm{C}$, anaerobic conditions (Anaerocult A, Merck, Darmstadt, Germany)). Hafnia sp. (Ha) was counted in double layer pour plates of Violet Red Bile Glucose agar (Biokar Diagnostic) after 2 days at $30^{\circ} \mathrm{C}$.

\section{Chemical analysis}

The $\mathrm{pH}$ value was measured with a pH-meter (Mettler Delta 320, AES, Combourg, France) in the mother solution prepared as described above for microbial analysis. Total volatile basic nitrogen (TVBN), trimethylamine (TMA) and trimethylamine-oxide (TMA-O) were determined in $100 \mathrm{~g}$ of flesh using the Conway micro-diffusion method (Conway and Byrne, 1933).

\section{Results}

\section{Individual groups of bacteria}

\section{Chemical changes}

The chemical results at day 0 and 17 are presented in Table 2. The data at day 3, 6, 9 and 13 are not shown as there is no major changes during storage. The control tuna flesh had a stable acidic $\mathrm{pH}$ all over the storage (average of $5.80 \pm 0.06$ ). The inoculated samples showed similar values of $\mathrm{pH}$ at the end of storage, except the groups $\mathrm{Pp}, \mathrm{Pg}$ and $\mathrm{Ha}$ that caused an alkalinisation of around 1.7, 0.8 and 1.4 units, respectively. At the beginning of storage, value of TVBN was equal to $20.3 \mathrm{mg}-\mathrm{N} 100$ $\mathrm{g}^{-1}$ and null for TMA. No significant productions of TVBN and TMA were noticed in the tuna flesh during 17 days of storage, both in control and in inoculated samples. 


\section{Enumeration of the bacterial strains}

The bacterial population changes in inoculated tuna samples stored for 17 days at $8^{\circ} \mathrm{C}$ are shown in Figure 1. The control count (non-inoculated flesh) remained below the detection threshold (1.7 $\mathrm{Log} \mathrm{CFU} \mathrm{g}^{-1}$ ) during all the storage period (data not shown). Initially, the TVC of the inoculated samples ranged between 4.5-5.3 Log CFU $g^{-1}$, except for Pp group with a level of 3.7 Log CFU g ${ }^{-1}$. At day 3, the counts of 3 groups (Pf, En and Es) ranged from 5.3 to $6.3 \mathrm{Log} \mathrm{CFU} \mathrm{g}^{-1}$ and the others (Se, Pp, $\mathrm{Ha}, \mathrm{Bx}, \mathrm{Ca}$ and $\mathrm{Pg}$ ) from 7.2 to $8.2 \mathrm{Log} \mathrm{CFU} \mathrm{g}^{-1}$. Thereafter, half of groups, including $\mathrm{Pf}, \mathrm{Bx}, \mathrm{Se}, \mathrm{Ca}$ and Es, reached their maximum count of approximately 8-9 Log CFU $\mathrm{g}^{-1}$ from 6 days of storage while the others continued to grow, especially $\mathrm{Pg}, \mathrm{Pp}$ and Ha with a level superior to 9-10 Log CFU g $^{-1}$ at the end of storage.

\section{Sensory quality}

Figure 2 shows the sensory spoilage score of the control and the inoculated samples during the aerobic storage at $8^{\circ} \mathrm{C}$. Figure 3 represents the standardized PCA performed with the mean scores of each odor descriptors. The descriptors and samples are simultaneously projected on the $1-2$ plane ( $61.5 \%$ of the inertia). The first axis (40.6\%) discriminates unspoiled samples with marine/fish, vegetal and grilled characteristics (right side of PCA) from spoiled samples with off-odors as sulfur/cabbage, amine, sour/fermented, feet/cheese, etc. (left side). The second axis (20.9\%) discriminates samples with pyrrolidine odor (upper part) from butter/caramel (lower part). The sensory quality of the control remained stable until 9 days $(<2)$, with marine/fish odor, and then presented slight sour/fermented and feet/cheese odors until the end of storage. The spoilage potential of the bacteria varied and three scenarios were observed. Scenario 1, no significant spoilage: groups Pg, Pf, Es and En did not spoil the tuna flesh. The score remained inferior to control (2-3) all over 
the storage with marine/fish and vegetal odors, except En after 17 days (score 5.0) for which some sulfur/cabbage and floor cloth off-odors were detected. Scenario 2, weak spoilage: groups $\mathrm{Bx}$ and $\mathrm{Ca}$, and in a different way $\mathrm{Pp}$, were considered as moderate spoilers. By the third day, Ca released butter/caramel (total spoilage score 3.4) and Bx sour/fermented, butter/caramel and acid fragrances (score 4.7). The sensory spoilage score then ranged between 4 to 5 all over the storage period and samples were represented on the lower part of the second PCA axis, essentially characterized by butter/caramel and acid odors. Ca group also released grilled odor at days 9 and 17. These samples were well represented on axis 3 of the PCA (inertia $10.6 \%$, data not shown). Pp group was considered as a moderate spoiler due to the result at day 9 when a degree of spoilage superior to the limit of acceptability (6.0) and sour/fermented and sulfur/cabbage odors were detected by the panellists. However, all the other days, even after day 9, the samples were not considered as spoiled when comparing to the control. Scenario 3, strong spoilage: Ha and Se were the strongest spoiling bacteria with a spoilage score exceeding the limit of acceptability (6) from day 6 and day 9 until the end of storage for $\mathrm{Ha}$ and Se respectively. These samples were located on the left upper part of PCA and characterized by unpleasant odors such as pyrrolidine, floor cloth, amine and sulfur/cabbage. The red/pink color of the tuna flesh disappeared during the aerobic storage of all samples, except for the most spoiled samples (Ha and $\mathrm{Se}$ ) and for the group Ca (data not shown).

This article is protected by copyright. All rights reserved. 


\section{Combination of bacterial groups}

\section{Chemical changes}

The initial $\mathrm{pH}$ of the control was similar to the first trial and no significant variations were observed for the control and inoculated samples (data not shown). The TVBN concentrations were around $20 \mathrm{mg}-\mathrm{N} 100 \mathrm{~g}^{-1}$ and the TMA remained negligible all along the storage. The fresh yellowfin tuna flesh did not contain TMA-O (data not shown).

\section{Enumeration of the bacterial strains}

The spoilage potential of five groups of bacteria (Bx, $\mathrm{Ca}, \mathrm{Ha}, \mathrm{Pp}$ and $\mathrm{Pfg}$ ) were tested in pair combination (Table 1). Pfg was a mix of Pf and Pg that did not spoiled the tuna flesh in the first trial whereas Pp lightly spoiled it. Those groups were selected because of their prevalence in spoiled tuna flesh (Silbande et al., 2016). The groups were inoculated by pair (10 mixes in total) and in a more complex association of $\mathrm{Bx}, \mathrm{Ha}, \mathrm{Pp}$ and Pfg. Figure 4 presents the growth curves of bacterial groups inoculated in tuna, alone or in combination. The control flesh remained below the detection threshold $\left(1.7 \mathrm{Log} \mathrm{CFU} \mathrm{g}^{-1}\right.$ ) during all the storage period (data not shown). Overall, the bacterial growth was weaker when the groups were coinoculated than alone and the differential at the end of storage was between 1 to 3 Log CFU g ${ }^{-1}$ depending on the combinations. As an example, Bx increased more rapidly alone and reached a rate of $9.2 \mathrm{Log} \mathrm{CFU} \mathrm{g}^{-1}$ at day 17 while in association with $\mathrm{Ca}, \mathrm{Ha}, \mathrm{Pp}, \mathrm{Pfg}$ and HaPpPfg, Bx never overpassed 6-7 Log CFU g ${ }^{-1}$. The greatest inhibition was observed for Pseudomonas. Indeed, Pp and Pfg counts were 4-5 Log CFU g ${ }^{-1}$ lower in mix culture with $\mathrm{Bx}$, Ca and Ha than in pure culture. In some case, the initial inoculum of Pseudomonas spp. was below the detection threshold (BxPp, HaPp and CaPfg) and this may explain the results. However, even 
with an inoculum of $5.2 \mathrm{Log} \mathrm{CFU} \mathrm{g}^{-1}$ ( $\mathrm{HaPfg}, \mathrm{CaPp}, \mathrm{BxPfg}$,) this genus was inhibited and a total prevention of growth was observed with $\mathrm{Ha}$ and $\mathrm{Ca}$. For the combination PpPfg, it was not possible to conclude as no selective medium was available to differentiate Pseudomonas species.

\section{Sensory quality}

Figure 5 shows the sensory spoilage score of the control and the inoculated samples obtained during the aerobic storage at $8^{\circ} \mathrm{C}$. The classification of samples according to their sensory characteristics is presented in the AHC based on the first five principal components of the standardized PCA that is obtained with the mean scores of profiling odors (Figure 6). The control was characterized by marine/fish, vegetal and rancid odor and the sensory spoilage score ranged between 3 to 4 . At day 6 , none of the bacterial mixes significantly spoiled the products (Figure 5) and just weak butter/caramel, floor cloth and sour/fermented odors were noticed. After 13 or 17 days, only 3 combinations allowed the sensory rejection: $\mathrm{BxCa}, \mathrm{HaPfg}$ and $\mathrm{CaHa}$. The samples were characterized by strong fecal and sulfur/cabbage odors and their spoilage score were approximately $7-8$. When Carnobacterium spp. was present, a sour/fermented odor was also significantly detected. All these samples were grouped at the left side of the AHC (Figure 6). All bacterial groups, even some considered as strong spoilers, combined with Pseudomonas spp. (Pp or Pfg) did not deteriorate the sensory quality of tuna, except HaPfg. The samples grouped together on the AHC with grilled and marine/fish odors, and sometimes butter/caramel, feet/cheese and sour/fermented odors. Surprisingly, the combination of the two Pseudomonas groups (PpPfg) led to feet/cheese odors that significantly increased the spoilage score to 5.6 at the end of storage. The last combination (BxHaPpPfg) was closed to the sensory acceptability limit at day 13 with a score of 5.5 and characterized by sour/fermented, 
floor cloth and pyrrolidine odors. Only pyrrolidine odor persisted at the end of storage and the spoilage score dropped to the same level as the control (4.1). At day 6, all the tuna samples, inoculated or not, presented a beige color with a score of approximately 5-7, except CaPfg that had a red/pink aspect (score 1.8). The control samples reached the maximum beige level of 7.7 at day 17 and presented a green discoloration of the flesh. Only the CaPfg combination had a similar trend. Surprisingly, the others led to a better red/pink color without green defects, particularly PpPfg, CaPp, HaPfg and CaHa (data not shown).

\section{Discussion}

The spoilage potential of bacterial species depends on the food matrix and storage conditions (Stohr et al., 2001; Macé et al., 2013, 2014; Pothakos et al., 2014;

Saraoui et al., 2016). The physicochemical properties of the tropical yellowfin tuna flesh, studied by Dromer et al., 2015, should favor the growth and spoilage activity of Pseudomonas spp. and various members of the family of Enterobacteriaceae and, depending on the storage conditions, of Carnobacterium spp. and B. thermosphacta because they grow well and able to metabolize the flesh constituents at $\mathrm{pH}<6$. Tropical fish (especially those without O-TMA) conduct to the bacterial formation of acetoin/diacetyl (butter/caramel or cheesy off-odors) and esters (fruity off-odors) (Gram et al., 2002; Dalgaard, 2005). In the previous research (Silbande et al., 2016), tuna microbiota was studied using the Illumina sequencing method and revealed a dominance of these bacteria in the spoiled yellowfin tuna responsible of strong amine off-odors. 
Except some cases of Pseudomonas, inoculations were performed at approximately 5 Log CFU g ${ }^{-1}$. This level was chosen to favor a fast colonization of the flesh and to rapidly observe the spoilage effect that usually occurs at the beginning of the stationary phase of bacterial growth (Gram and Huss, 1996). All cultures tested grew well on tuna cubes but the unpleasant odors appeared only for some groups of strains, which is in accordance with the SSO concept (Gram and Dalgaard, 2002). For each group, a mix of 2 to 4 strains per species was used to avoid the strain effect described by Stohr et al. (2001) and Pothakos et al. (2014). From the $3^{\text {rd }}$ day, 4 bacterial groups released significant off-odors. Bx and $\mathrm{Ca}$ emitted butter and sour odors while Se and Ha were characterized by pyrrolidine-like odors. Except for the Ca group, all the off-odors persisted in the samples and even led to the rejection of the product by the sensory panel for Se and Ha. Mesophilic enteric bacteria, especially the species $S$. liquefaciens and $H$. alvei, are identified as strong spoilers of meat, fish and seafood and are often associated with the production of malodorous diamines such as putrescine and cadaverine (Joffraud et al., 2001; Stohr et al., 2001; Ercolini et al., 2009; Doulgeraki et al., 2011; Jaffrès et al., 2011; Macé et al., 2013). The growth of these two organisms in red meat may cause a green discoloration probably due to the interaction between bacterial metabolites and myoglobin (Stanbridge and Davies, 1998). This has not been observed in this study where diced tuna inoculated with Se and Ha kept their red color, whereas the control became grey and green. Under controlled storage conditions (vacuum, modified atmosphere), members of Enterobacteriaceae are able to degrade TMA-O to TMA creating ammonia-like off-odors (Jørgensen et al., 2001; Gram and Dalgaard, 2002). However, no production of TMA or TVBN was observed in the samples inoculated with Se, Ha, En and Es. The spoilage role of $C$. divergens 
and $C$. maltaromaticum is variable in meat and fish products, despite their ability to metabolize amino-acids and released unpleasant odors (Laursen et al., 2005). In cold-smoked salmon, these organisms have a limited spoilage activity (Joffraud et al., 2001; Stohr et al., 2001; Brillet et al., 2005) such as in tuna. Brillet et al. (2005) and Laursen et al. $(2005,2006)$ even showed that $C$. maltaromaticum may be applicable as protective cultures. Conversely, $B$. thermosphacta is often listed as a spoiling bacteria in meat and fish products (Vermeiren et al., 2005; Papadopoulou et al., 2012, 2013), capable to produce ketones, acids and alcohols (Joffraud et al., 2001). This bacteria released strong butter, sour and nauseous off-odors in chilled and MAP cooked peeled shrimps (Laursen et al., 2006; Jaffrès et al., 2011). The inoculation in sterile cold-smoked salmon revealed that $B$. thermosphacta and $C$. maltaromaticum were characterized by 2-heptanone (blue-cheese odor) and 2,3butanedione (butter smell), respectively (Joffraud et al., 2001). Pseudomonas spp. are commonly classified as major spoiling bacteria of chilled fish stored in air (García-López et al., 2004; Hovda et al., 2007; Parlapani et al., 2013, 2014, 2015a, 2015b; Parlapani and Boziaris, 2016). In tuna, Pg and Pf groups exhibited weak influence on the sensory quality despite a rapid growth up to 9-10 Log CFU g ${ }^{-1}$. The Pp group developed a peak of strong off-odors at the middle storage period and then a moderate butter/caramel flavor. This could be due to a loss of some volatile compounds in the air. For this group of Pseudomonas, panellists noted "vanilla" and "lemon" odors that are close to the sweet and fruity odors described during the inoculation of Ps. fragi in sterile fish matrices (Gennari et al., 1999; Ólafsdóttir et al., 2006). The sensory differences observed between the Pseudomonas groups are in accordance with the fact that the spoilage potential of this genus is speciesdependent (Dogan and Boor, 2003; Morales et al., 2005; Arslan et al., 2011). 
Joffraud et al. (2006) and Macé et al. (2013) have evidenced the effect of bacterial interactions on spoilage of seafood. Table 3 summarized the maximum spoilage score and significant odors developed in tuna inoculated with individual groups of bacteria and combinations of groups during the aerobic storage at $8^{\circ} \mathrm{C}$. Ha was the greatest spoiling group. In association with $\mathrm{Bx}$ or $\mathrm{Pp}$, which are individually considered as mildly spoilers, very weak off-odors were released. This may be attributed to the inhibition of Ha growth, which reached around $10 \mathrm{Log} \mathrm{CFU} \mathrm{g}^{-1}$ in pure culture and 8 in co-culture. The odors of $\mathrm{Ha}$ alone were similar to $\mathrm{Ha}$ with $\mathrm{Ca}$ or Pfg. Contrary to the study of Macé et al. (2013) in salmon flesh, Ca did not inhibit the growth of Ha. However, Pfg did inhibit $\mathrm{Ha}$, in the same proportion as $\mathrm{Bx}$ and $\mathrm{Pp}$. Some metabiosis phenomena may explain this result and still need to be explored. All the associations with Bx exhibit the same sensory characteristics as Bx alone, except with $\mathrm{Ca}$. Surprisingly, Bx and $\mathrm{Ca}$ which are weak spoilers when alone, strongly deteriorated the quality of flesh and the odors were comparable to naturally contaminated flesh at the end of storage, observed by Silbande et al. (2016). The spoiling effect obtained with the association of $B$. thermosphacta and Carnobacterium spp. has already been mentioned by Mejlholm et al. (2005) in cooked and peeled MAP shrimps. However, this result was not reproduced during the similar study of Laursen et al. (2006). In most cases, the presence of some Pseudomonas spp. (Pp or Pfg group) lowered the spoiling intensity of the other groups and this is particularly true for the HaPp mix. The combination of all the Pseudomonas groups (PpPfg) had the same maximum spoilage score as Pp but emitted different odors than the single spoilage groups $(\mathrm{Pp}, \mathrm{Pf}$ and $\mathrm{Pg})$ probably due to the mixture of all the metabolites individually produced. 
The main output of this study is that most of the Pseudomonas species tested do not spoil tuna, although this genus is often incriminated, as it dominates the microbiota at the sensory rejection time. Moreover, Pseudomonas spp. tends to attenuate the spoilage of other bacteria, which has not been reported in literature. $B$. thermosphacta and Carnobacterium spp. are moderate spoilers, with butter/caramel odors. H. paralvei and Serratia spp. are strong spoilers with fecal or sulfur odors. Therefore, the count of enterobacteria seems a better indicator of spoilage than the Pseudomonas one. The co-inoculations highlight the bacterial interactions conducting to an enhancement or an inhibition of the spoilage potential in the tuna flesh. When Carnobacterium spp. are combined with $H$. paralvei or $B$. thermosphacta, the odor profile is close to the naturally contaminated tuna stored on the same conditions and these associations could correspond to the SSO. A microbial ecosystem similar to that found by Silbande et al. (2016) (Bx, Ca, Ha, Pp, Pfg) did not reproduce the sensory quality of the tuna with its endogenous microbiota. No classical physico-chemical parameters such as $\mathrm{pH}$, TVBN and TMA correlated with the spoilage process. More knowledge on the bacterial species metabolism is necessary to predict spoilage and manage the preservative techniques.

\section{Acknowledgements}

This research was financially supported by the territorial community of Martinique and the European Fisheries Fund (joint convention number:

013/DM/0335/3.1.1.a/38836). The authors are grateful to T. Guerrier for its valued contribution. 


\section{Conflict of interest}

All the authors approved the manuscript and its submission to the Journal of Applied

Microbiology and declare having no competing interest in this work.

\section{References}

AFNOR (1995) NF V 09-105. Directives générales pour l'implantation de locaux destinés à l'analyse sensorielle. Contrôle de la qualité des produits alimentaires - Analyse sensorielle.

Alfaro, B., Hernández, I., Le Marc, Y. and Pin, C. (2013) Modelling the effect of the temperature and carbon dioxide on the growth of spoilage bacteria in packed fish products. Food control 29, 429-437.

Arslan, S., Eyi, A. and Özdemir, F. (2011) Spoilage potentials and antimicrobial resistance of Pseudomonas spp. isolated from cheeses. J Dairy Sci 94, 58515856.

Brillet, A., Pilet, M.F., Prevost, H., Cardinal, M. and Leroi, F. (2005) Effect of inoculation of Carnobacterium divergens V41, a biopreservative strain against Listeria monocytogenes risk, on the microbiological, chemical and sensory quality of cold-smoked salmon. Int J Food Microbiol 104 (3), 309-324.

Cerveny, J., Meyer, J.D. and Hall, P.A. (2009) Microbiological spoilage of meat and poultry products. In: Sperber,W.H., Doyle,M.P. (Eds.), Compendium of the Microbiological Spoilage of Foods and Beverages. Springer, New York, pp. 87120.

Chaillou, S., Chaulot-Talmon, A., Caekebeke, H., Cardinal, M., Christieans, S., Denis, C., Desmonts, M.H., Dousset, X., Feurer, C., Hamon, E., Joffraud, J.J., La Carbona, S., Leroi, F., Leroy, S., Lorre, S., Macé, S., Pilet, M.F., Prévost, H., Rivollier, M., Roux, D., Talon, R., Zagorec, M. and Champomier-Vergès, M.C. (2015) Origin and ecological selection of core and food-specific bacterial communities associated with meat and seafood spoilage. ISME J 9, 1105-1118.

Conway, E.J. and Byrne, A. (1933) An absorption apparatus for the microdetermination of certain volatile substances: The micro-determination of ammonia. Biochem J 27 (2), 419-429. 
Dalgaard, P. (2005) Microbiology of marine muscle foods. In: Hui, Y.H. (Ed.), Handbook of Food Science, Technology and Engineering. CRC press, USA, vol. 149.

Davidson, C.M. and Cronin, F. (1973) Medium for the selective enumeration of lactic acid bacteria from foods. Appl Microbiol 26 (3), 439-440.

Dogan, B. and Boor, K.J. (2003) Genetic diversity and spoilage potentials among Pseudomonas spp. isolated from fluid milk products and dairy processing plants. Appl Environ Microbiol 69 (1), 130-138.

Doulgeraki, A.I., Paramithiotis, S. and Nychas, G.J.E. (2011) Characterization of the Enterobacteriaceae community that developed during storage of minced beef under aerobic or modified atmosphere packaging conditions. Int J Food Microbiol 145, 77-83.

Dromer, C., Eugene, S., Régina, F., Reynal, L., Etienne, M., Mathieu, H., Pau, C. (2015) Etude de la qualité des produits de la pêche associée aux DCP ancrés (Study of the quality of fishery products associated with anchored FADs). Project MAGDELESA. R.INT.RBE/BIODIVENV 2015-2, 123p.

Du, W.X., Kim, J., Cornell, J.A., Huang, T.S., Marshall, M.R. and Wei, C.I. (2001) Microbiological, sensory, and electronic nose evaluation of yellowfin tuna under various storage conditions. J Food Prot 64 (12), 2027-2036.

Du, W.X., Lin, C.M., Phu, A.T., Cornell, J.A., Marshall, M.R. and Wei, C.I. (2002) Development of biogenic amines in yellowfin tuna (Thunnus albacares): Effect of storage and correlation with decarboxylase-positive bacterial flora. J Food Sci 67 (1), 292-301.

Emborg, J., Laursen, B.G. and Dalgaard, P. (2005) Significant histamine formation in tuna (Thunnus albacares) at $2^{\circ} \mathrm{C}$-effect of vacuum-and modified atmospherepackaging on psychrotolerant bacteria. Int J Food Microbiol 101, 263-279.

Ercolini, D., Russo, F., Nasi, A., Ferranti, P. and Villani, F. (2009) Mesophilic and psychrotrophic bacteria from meat and their spoilage potential in vitro and in beef. Appl Environ Microbiol 75 (7), 1990-2001.

FAO, 2016. The state of world fisheries and aquaculture 2016. Rome. 227 pp. URL: http://www.fao.org/3/a-i5555f.pdf (June 2017).

Ferrario, C., Pegollo, C., Ricci, G., Borgo, F. and Fortina, M.G. (2012) PCR detection and identification of histamine-forming bacteria in filleted tuna fish samples. $\mathrm{J}$ Food Sci 77 (2), M115-M120. 
Franzetti, L., Scarpellini, M., Mora, D. and Galli, A. (2003) Carnobacterium spp. in seafood packaged in modified atmosphere. Ann Microbiol 53, 189-198.

García-López, I., Otero, A., García-López, M. L. and Santos, J. A. (2004) Molecular and phenotypic characterization of nonmotile Gram-negative bacteria associated with spoilage of freshwater fish. J Appl Microbiol 96(4), 878-886.

Gennari, M., Tomaselli, S. and Cotrona, V. (1999) The microflora of fresh and spoiled sardines (Sardina pilchardus) caught in Adriatic (Mediterranean) Sea and stored in ice. Food Microbiol 16, 15-28.

Ghaly, A.E., Dave, D., Budge, S. and Brooks, M.S. (2010) Fish spoilage mechanisms and preservation techniques: review. Am J Appl Sci 7 (7), 859-877. González-Rodríguez, M.N., Sanz, J.J., Santos, J.Á, Otero, A. and García-López, M.L. (2002) Numbers and types of microorganisms in vacuum-packed coldsmoked freshwater fish at the retail level. Int J Food Microbiol 77, 161-168.

Gram, L. and Huss, H.H. (1996). Microbiological spoilage of fish and fish products. Int J Food Microbiol 33, 121-137.

Gram, L. and Huss, H.H. (2000) Fresh and processed fish and shellfish. In: Lund,B.M., Baird-Parker,T.C., Gould,G.W. (Eds.), The Microbiological Safety and Quality of Food. Aspen Publishers, Gaithersburg, pp. 472-506.

Gram, L. and Dalgaard, P. (2002) Fish spoilage bacteria-problems and solutions. Curr Opin Biotechnol 13, 262-266.

Gram, L., Ravn, L., Rasch, M., Bruhn, J.B., Christensen, A.B., Givskov, M. (2002) Food spoilage-interactions between food spoilage bacteria. Int J Food Microbiol 78, 79-97.

Gram, L. (2009) Microbiological spoilage of fish and seafood products. In: Sperber,W.H., Doyle,M.P. (Eds.), Compendium of the Microbiological Spoilage of Foods and Beverages. Springer, New York, pp. 87-120.

Guizani, N., Al-Busaidy, M.A., Al-Belushi, I.M., Mothershaw, A. and Rahman, M.S. (2005) The effect of storage temperature on histamine production and the freshness of yellowfin tuna (Thunnus albacares). Food Res Int 38, 215-222.

Hovda, M. B., Sivertsvik, M., Lunestad, B. T., Lorentzen, G. and Rosnes, J. T. (2006) Characterisation of the dominant bacterial population in modified atmosphere packaged farmed halibut (Hippoglossus hippoglossus) based on 16S rDNADGGE. Food Microbiol 24(4), 362-371. 
Hovda, M. B., Lunestad, B. T., Sivertsvik, M. and Rosnes, J. T. (2007)

Characterisation of the bacterial flora of modified atmosphere packaged farmed Atlantic cod (Gadus morhua) by PCR-DGGE of conserved 16S rRNA gene regions. Int J Food Microbiol 117(1), 68-75.

Jaffrès, E., Lalanne, V., Macé, S., Cornet, J., Cardinal, M., Sérot, T., Dousset, X. and Joffraud, J.J. (2011) Sensory characteristics of spoilage and volatile compounds associated with bacteria isolated from cooked and peeled tropical shrimps using SPME-GC-MS analysis. Int J Food Microbiol 147, 195-202.

Joffraud, J.J., Leroi, F., Roy, C. and Berdagué, J.L. (2001) Characterisation of volatile compounds produced by bacteria isolated from the spoilage flora of coldsmoked salmon. Int J Food Microbiol 66, 175-184.

Joffraud, J.J., Cardinal, M., Cornet, J., Chasles, J.S., Léon, S., Gigout, F. and Leroi, F. (2006) Effect of bacterial interactions on the spoilage of cold-smoked salmon. Int J Food Microbiol 112, 51-61.

Jørgensen, L.V., Huss, H.H. and Dalgaard, P. (2001) Significance of volatile compounds produced by spoilage bacteria in vacuum-packed cold-smoked salmon (Salmo salar) analyzed by GC-MS and multivariate regression. J Agric Food Chem 49, 2376-2381.

Laursen, B.G., Bay, L., Cleenwerck, I., Vancanneyt, M., Swings, J., Dalgaard, P. and Leisner, J.J. (2005) Carnobacterium divergens and Carnobacterium maltaromaticum as spoilers or protective cultures in meat and seafood: phenotypic and genotypic characterization. Syst Appl Microbiol 28, 151-164.

Laursen, B.G., Leisner, J.J. and Dalgaard, P. (2006) Carnobacterium species: effect of metabolic activity and interaction with Brochothrix thermosphacta on sensory characteristics of modified atmosphere packed shrimp. J Agric Food Chem 54 (10), 3604-3611.

Leroi, F., Joffraud, J.J., Chevalier, F. and Cardinal, M. (2001) Research of quality indices for cold-smoked salmon using a stepwise multiple regression of microbiological counts and physico-chemical parameters. J Appl Microbiol 90 (4), 578-587.

Leroi, F. (2010) Occurrence and role of lactic acid bacteria in seafood products. Food Microbiol 27 (6), 698-709. 
Leroi, F. and Joffraud, J.J. (2011) Microbial degradation of seafood. In: Montet,D., Ramesh,C.R. (Eds.), Aquaculture Microbiology and Biotechnology. Science Publisher and CRC Press, vol. 2, New Hampshire, pp. 47-72.

Macé, S., Cornet, J., Chevalier, F., Cardinal, M., Pilet, M.F., Dousset, X. and Joffraud, J.J. (2012) Characterisation of the spoilage microbiota in raw salmon (Salmo salar) steaks stored under vacuum or modified atmosphere packaging combining conventional methods and PCR-TTGE. Food Microbiol 30 (1), 164172.

Macé, S., Joffraud, J.J., Cardinal, M., Malcheva, M., Cornet, J., Lalanne, V., Chevalier, F., Sérot, T., Pilet, M.F. and Dousset, X. (2013) Evaluation of the spoilage potential of bacteria isolated from spoiled raw salmon (Salmo salar) fillets stored under modified atmosphere packaging. Int J Food Microbiol 160 (3), 227-238.

Macé, S., Cardinal, M., Jaffrès, E., Cornet, J., Lalanne, V., Chevalier, F., Sérot, T., Pilet, M.F., Dousset, X. and Joffraud, J.J. (2014) Evaluation of the spoilage potential of bacteria isolated from spoiled cooked whole tropical shrimp (Penaeus vannamei) stored under modified atmosphere packaging. Food Microbiol 40, 9-17.

Mejlholm, O., Bøknæs, N. and Dalgaard, P. (2005) Shelf life and safety aspects of chilled cooked and peeled shrimps (Pandalus borealis) in modified atmosphere packaging. J Appl Microbiol 99, 66-76.

Morales, P., Fernández-García, E. and Nuñez, M. (2005) Volatile compounds produced in cheese by Pseudomonas strains of dairy origin belonging to six different species. J Agric Food Chem 53, 6835-6843.

Ólafsdóttir, G., Lauzon, H.L., Martinsdottir, E. and Kristbergsson, K. (2006) Influence of storage temperature on microbial spoilage characteristics of haddock fillets (Melanogrammus aeglefinus) evaluated by multivariate quality prediction. Int $\mathrm{J}$ Food Microbiol 111, 112-125.

Olofsson, T. C., Ahrné, S. and Molin, G. (2007) The bacterial flora of vacuum-packed cold-smoked salmon stored at $7^{\circ} \mathrm{C}$, identified by direct $16 \mathrm{~S}$ rRNA gene analysis and pure culture technique. J Appl Microbiol 103(1), 109-119.

Papadopoulou, O.S., Doulgeraki, A.I., Botta, C., Cocolin, L. and Nychas, G.J.E. (2012) Genotypic characterization of Brochothrix thermosphacta isolated during 
storage of minced pork under aerobic or modified atmosphere packaging conditions. Meat Sci 92, 735-738.

Papadopoulou, O.S., Panagou, E.Z., Mohareb, F.R. and Nychas, G.J.E. (2013) Sensory and microbiological quality assessment of beef fillets using a portable electronic nose in tandem with support vector machine analysis. Food Res Int 50, 241-249.

Parlapani, F. F., Meziti, A., Kormas, K. A. and Boziaris, I. S. (2013) Indigenous and spoilage microbiota of farmed sea bream stored in ice identified by phenotypic and 16S rRNA gene analysis. Food Microbiol 33(1), 85-89.

Parlapani, F. F., Mallouchos, A., Haroutounian, S. A. and Boziaris, I. S. (2014) Microbiological spoilage and investigation of volatile profile during storage of sea bream fillets under various conditions. Int J Food Microbiol 189, 153-163.

Parlapani, F. F., Verdos, G. I., Haroutounian, S. A. and Boziaris, I. S. (2015a) The dynamics of Pseudomonas and volatilome during the spoilage of gutted sea bream stored at $2^{\circ} \mathrm{C}$. Food Control 55, 257-265.

Parlapani, F. F., Haroutounian, S. A., Nychas, G. J. E. and Boziaris, I. S. (2015b) Microbiological spoilage and volatiles production of gutted European sea bass stored under air and commercial modified atmosphere package at $2{ }^{\circ} \mathrm{C}$. Food Microbiol 50, 44-53.

Parlapani, F. F. and Boziaris, I. S. (2016) Monitoring of spoilage and determination of microbial communities based on 16S rRNA gene sequence analysis of whole sea bream stored at various temperatures. LWT-Food Sci Technol 66, 553-559.

Pothakos, V., Nyambi, C., Zhang, B.Y., Papastergiadis, A., De Meulenaer, B. and Devlieghere, F. (2014) Spoilage potential of psychrotrophic lactic acid bacteria (LAB) species: Leuconostoc gelidum subsp. gasicomitatum and Lactococcus piscium, on sweet bell pepper (SBP) simulation medium under different gas compositions. Int J Food Microbiol 178, 120-129.

Saraoui, T., Leroi, F., Björkroth, J. and Pilet, M.F. (2016) Lactococcus piscium: a psychrotrophic lactic acid bacterium with bioprotective or spoilage activity in food-a review. J Appl Microbiol 121 (4), 907-918.

Sika, A.E., Ake Assi, Y., Koffi-Nevry, R. and Biego, H. (2014) Histamine contents in tuna loins (Thunnus sp.) produced in côte d'ivoire and its relation with bacterial load. Int J Sci Res 3 (6), 2347-2351. 
Silbande, A., Adenet, S., Smith-Ravin, J., Joffraud, J.J., Rochefort, K. and Leroi, F. (2016) Quality assessment of ice-stored tropical yellowfin tuna (Thunnus albacares) and influence of vacuum and modified atmosphere packaging. Food Microbiol 60, 62-72.

Stanbridge, L. and Davies, A. (1998) 6 The microbiology of chill-stored meat. In: Board,R.G., Davies,A.R. (Eds.), The Microbiology of Meat and Poultry. Blackie Academic and Professional, London, pp. 174-219.

Stohr, V., Joffraud, J.J., Cardinal, M. and Leroi, F. (2001) Spoilage potential and sensory profile associated with bacteria isolated from cold-smoked salmon. Food Res Int 34, 797-806.

Van Spreekens, K.J.A. (1974) The suitability of a modification of Long and Hammer's medium for the enumeration of more fastidious bacteria from fresh fishery products. Arch Lebensmittelhyg 25 (10), 213-219.

Vermeiren, L., Devlieghere, F., De Graef, V. and Debevere, J. (2005) In vitro and in situ growth characteristics and behaviour of spoilage organisms associated with anaerobically stored cooked meat products. J Appl Microbiol 98, 33-42.

\section{List of figures}

Figure 1: Growth of 9 bacterial groups inoculated in tuna cubes stored in aerobic conditions at $8^{\circ} \mathrm{C}$.

Figure 2: Spoilage score determined by the sensory panel $(n=12)$ for the control and the inoculated groups at each sampling date. Columns marked with an asterisk $\left({ }^{*}\right)$ are significantly higher than the control at the same date of analyses (ANOVA, $p<0.001)$.

Figure 3: Standardized Principal component analysis (PCA) performed with the mean scores of profiling odors: simultaneous representation of inoculated tuna samples and odor descriptors on plane 1-2 (61.5\% of inertia). Ellipses indicate groups of samples with similar odors. Numbers in labels of samples express duration of storage (in days).

Figure 4: Bacterial growth of the groups for single-group (solid line) and combined (dotted) cultures inoculated in tuna cubes stored in aerobic conditions at $8^{\circ} \mathrm{C}$. 
Figure 5: Spoilage score determined by the sensory panel $(n=14)$ for the control and the inoculated combinations at each sampling date. Columns marked with an asterisk $\left({ }^{*}\right)$ are significantly higher than the control at the same date of analyses (ANOVA, $p<0.001$ ).

Figure 6: Ascending hierarchical clustering (AHC) based on the first five principal components of the standardized PCA obtained with the mean scores of profiling odors. Ellipses indicate the cut of the tree in four groups of samples including similar odors. Numbers in labels of samples express duration of storage (in days). 
Table 1: Bacterial species inoculated in tropical yellowfin tuna for the two trials of experiments

\begin{tabular}{|c|c|c|}
\hline Trials & Bacterial species (strains SYP*) & Labels \\
\hline \multirow{10}{*}{$\begin{array}{l}\text { Groups } \\
\text { (mix of strains) }\end{array}$} & Control & C \\
\hline & Brochothrix thermosphacta (SYP3105, SYP3111, SYP3123, SYP3149) & $\mathrm{Bx}$ \\
\hline & Pseudomonas psychrophila/fragi (SYP3102, SYP3114, SYP3124, SYP3130) & $\mathrm{Pp}$ \\
\hline & Pseudomonas fluorescens, fulva, monteilii/plecoglossicida (SYP3139, SYP3140, SYP3161, SYP3162) & Pf \\
\hline & Pseudomonas gessardii/libanensis/synxantha, cedrina (SYP3116, SYP3117, SYP3118, SYP3138) & $\mathrm{Pg}$ \\
\hline & Carnobacterium divergens, maltaromaticum (SYP3141B, SYP3142) & $\mathrm{Ca}$ \\
\hline & Hafnia paralvei (SYP3128, SYP3136, SYP3137, SYP3143) & $\mathrm{Ha}$ \\
\hline & Serratia grimesii/liquefaciens/proteamaculans (SYP3122, SYP3135) & Se \\
\hline & Enterobacter asburiae/cancerogenus (SYP3157, SYP3158) & En \\
\hline & Escherichia hermanii (SYP3159, SYP3160) & Es \\
\hline \multirow{12}{*}{$\begin{array}{l}\text { Combinations } \\
\text { (mix of groups, a } \\
\text { group contains } \\
\text { all the strains } \\
\text { listed above) }\end{array}$} & Control & C \\
\hline & B. thermosphacta + Ps. psychrophila/fragi & BxPp \\
\hline & B. thermosphacta + Ps. fluorescens, fulva, monteilii/plecoglossicida + Ps. gessardii/libanensis/synxantha, cedrina & BxPfg \\
\hline & B. thermosphacta + H. paralvei & $\mathrm{BxHa}$ \\
\hline & B. thermosphacta + C. divergens, maltaromaticum & $\mathrm{BxCa}$ \\
\hline & Ps. psychrophila/fragi + Ps. fluorescens, fulva, monteilii/plecoglossicida + Ps. gessardii/libanensis/synxantha, cedrina & PpPfg \\
\hline & H. paralvei + Ps. psychrophila/fragi & HaPp \\
\hline & C. divergens, maltaromaticum + Ps. psychrophila/fragi & CaPp \\
\hline & H. paralvei + Ps. fluorescens, fulva, monteilii/plecoglossicida + Ps. gessardii/libanensis/synxantha, cedrina & HaPfg \\
\hline & C. divergens, maltaromaticum + Ps. fluorescens, fulva, monteilii/plecoglossicida + Ps. gessardii/libanensis/synxantha, cedrina & CaPfg \\
\hline & C. divergens, maltaromaticum + H. paralvei & $\mathrm{CaHa}$ \\
\hline & B. thermosphacta + H. paralvei + Ps. psychrophila/fragi + Ps. fluorescens, fulva, monteilii/plecoglossicida + Ps. gessardii/libanensis/synxantha, cedrina & BxHaPpPfg \\
\hline
\end{tabular}

*SYP: strain code in the bacterial collection of Ifremer.

This article is protected by copyright. All rights reserved. 
Table 2: Total volatile basic nitrogen (TVBN), trimethylamine (TMA) (mg-N $100 \mathrm{~g}^{-1}$ ) and $\mathrm{pH}$ measurements after 17 days of aerobic storage at $8^{\circ} \mathrm{C}$ in the samples inoculated with 9 groups of bacteria

\begin{tabular}{lllllllllllll}
\hline Groups & $\begin{array}{l}\text { Control } \\
\text { (day 0) }\end{array}$ & $\begin{array}{l}\text { Control } \\
\text { (day 17) }\end{array}$ & Bx & Pp & Pf & Pg & Ca & Ha & Se & En & Es \\
\hline TVBN & 20.34 & 18.93 & 19.40 & 18.20 & 22.66 & 19.59 & 19.73 & 19.76 & 20.21 & 16.58 & 20.17 \\
TMA & 0.00 & 0.66 & 1.08 & 1.10 & 1.39 & 1.35 & 1.47 & 2.71 & 3.51 & 1.07 & 1.83 \\
pH & 5.76 & 5.84 & 5.92 & 7.53 & 5.69 & 6.55 & 5.57 & 7.20 & 5.73 & 5.68 & 5.74 \\
\hline
\end{tabular}

This article is protected by copyright. All rights reserved. 
Table 3: Maximum spoilage score (scale 0-10) and significant odors developed in tuna inoculated with individual groups of bacteria (gray cells) and combinations of groups, during the aerobic storage at $8^{\circ} \mathrm{C}$

\begin{tabular}{|c|c|c|c|c|c|}
\hline & $\mathrm{Bx}$ & & & & \\
\hline$B x$ & $\begin{array}{c}5 \\
\text { butter/caramel }\end{array}$ & $\mathrm{Pp}$ & & & \\
\hline $\mathrm{Pp}$ & $\begin{array}{c}3 \\
\text { sour/fermented } \\
\text { butter/caramel }\end{array}$ & $\begin{array}{c}7 \\
\text { sour/fermented } \\
\text { sulfur/cabbage } \\
\text { "fruity, acid" }\end{array}$ & Pfg & & \\
\hline Pfg & $\begin{array}{c}4 \\
\text { butter/caramel }\end{array}$ & $\begin{array}{c}6 \\
\text { sour/fermented }\end{array}$ & 2 & $\mathrm{Ha}$ & \\
\hline $\mathrm{Ha}$ & $\begin{array}{c}3 \\
\text { butter/caramel }\end{array}$ & $\begin{array}{c}4 \\
\text { sulfur/cabbage }\end{array}$ & $\begin{array}{c}\mathbf{8} \\
\text { fecal } \\
\text { sulfur/cabbage }\end{array}$ & $\begin{array}{c}9 \\
\text { sulfur/cabbage } \\
\text { pyrrolidine } \\
\text { "fecal" }\end{array}$ & $\mathrm{Ca}$ \\
\hline $\mathrm{Ca}$ & $\begin{array}{c}7 \\
\text { fecal } \\
\text { sour/fermented } \\
\text { sulfur/cabbage }\end{array}$ & $\begin{array}{c}4 \\
\text { butter/caramel }\end{array}$ & $\begin{array}{c}3 \\
\text { sour/fermented }\end{array}$ & $\begin{array}{c}8 \\
\text { fecal } \\
\text { sulfur/cabbage } \\
\text { sour/fermented }\end{array}$ & $\begin{array}{c}5 \\
\text { butter/caramel } \\
\text { sour/fermented } \\
\text { grilled }\end{array}$ \\
\hline
\end{tabular}

*Odors in brackets were not comprised in the list of descriptors but added by the panellists to describe the sample.

${ }^{\star *}$ Bold text indicate the sample with a spoilage score superior to the limit of acceptability of 6/10.

This article is protected by copyright. All rights reserved. 


\section{Figure 1}

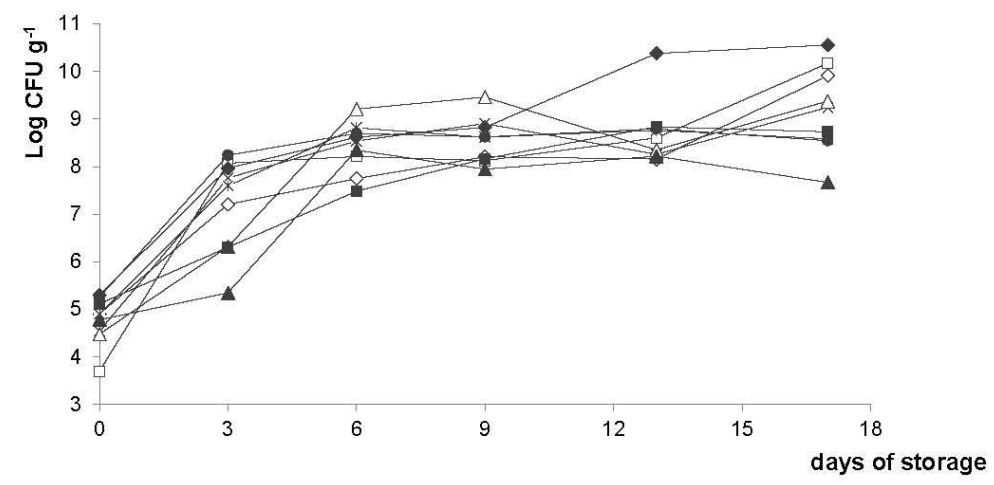

Legend:

$(x): B x$

(ㅁ): $\mathrm{Pp}$

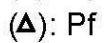

(১): $\mathrm{Pg}$

(*): $\mathrm{Ca}$

$(\diamond): \mathrm{Ha}$

(e): $\mathrm{Se}$

(घ): En

(A): Es

This article is protected by copyright. All rights reserved. 
Figure 2

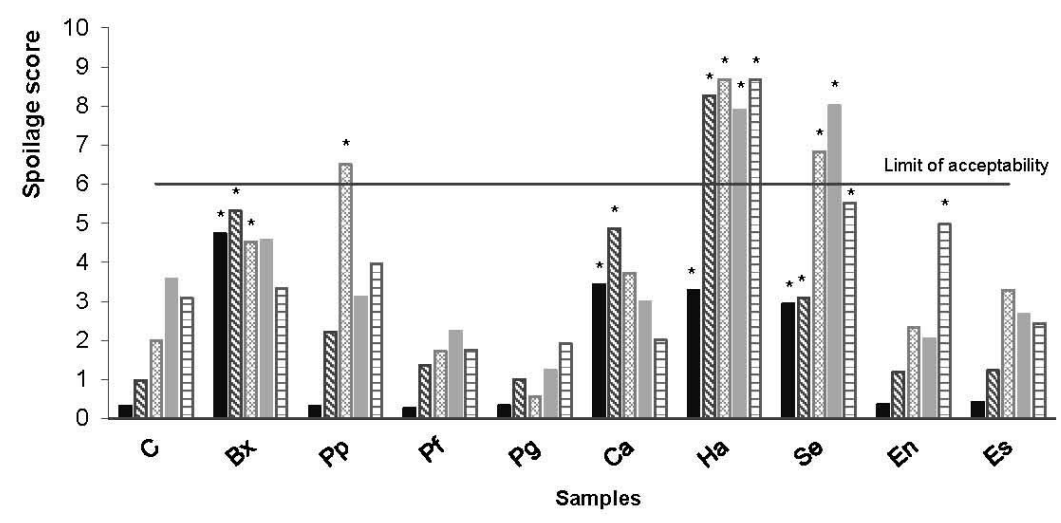
Legend:
(匹): day 3
(\$): day 6
(ब): day 9
$(\bullet)$ : day 13
(घ): day 17

This article is protected by copyright. All rights reserved. 
Figure 3

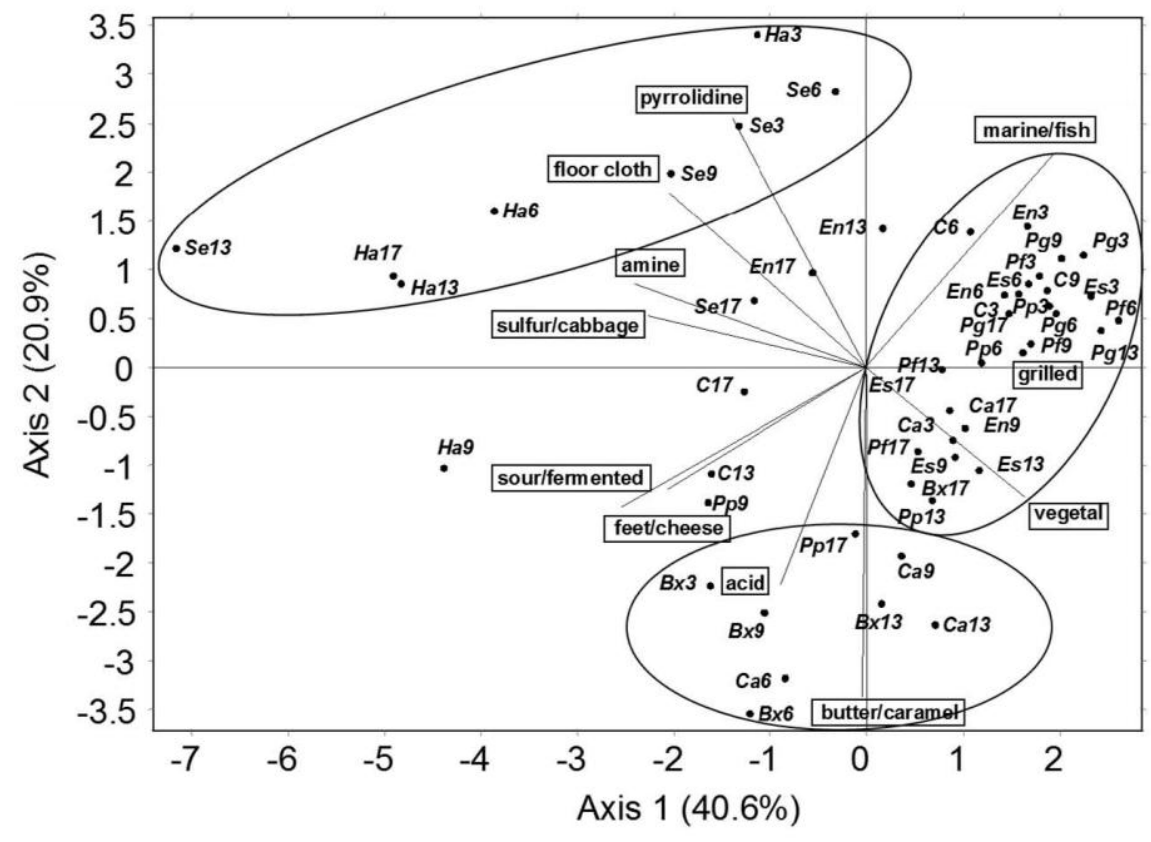

This article is protected by copyright. All rights reserved. 
Figure 4
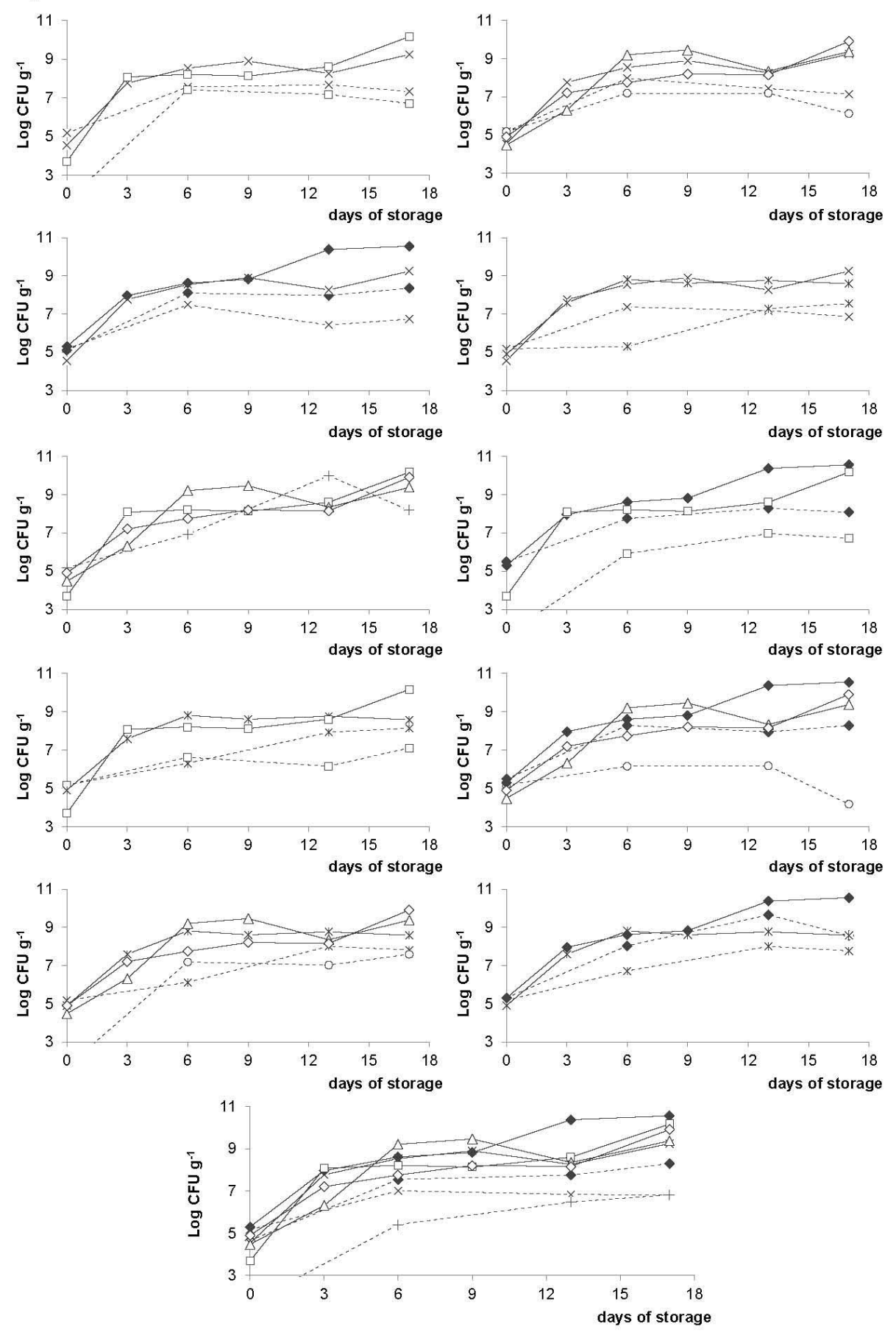

This article is protected by copyright. All rights reserved. 

Legend:
(x): Bx
(): $\mathrm{Pp}$
$(\Delta): P f$
$(\diamond): P g$
(o): $\mathrm{Pfg}$ (mix of $\mathrm{Pf}$ and $\mathrm{Pg}$ )
$(+)$ : PpPfg (mix of Pp, Pf and Pg)
$(*): \mathrm{Ca}$
$(\diamond): \mathrm{Ha}$
$(\bullet): \mathrm{Se}$
(ब): En
$(\boldsymbol{\Lambda})$ : Es

This article is protected by copyright. All rights reserved. 


\section{Figure 5}

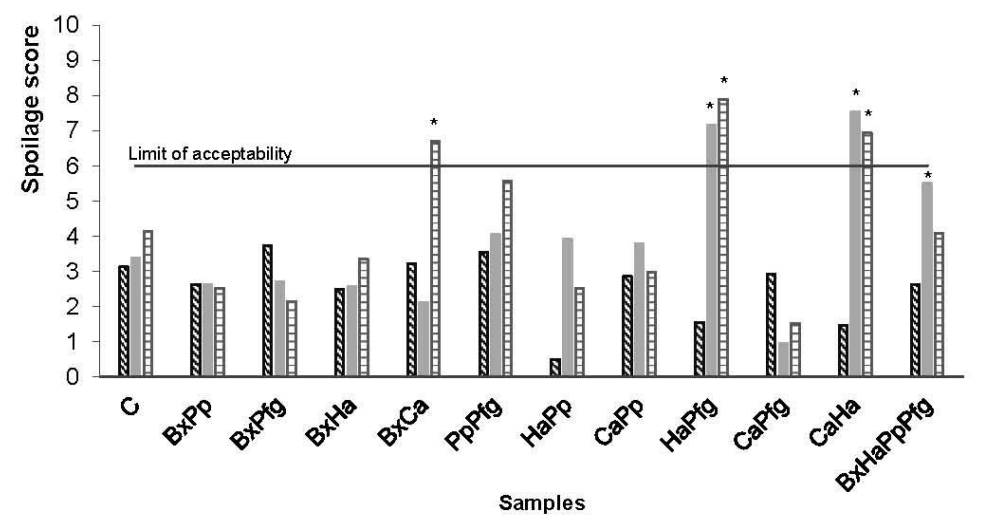

Legend:

$(\mathbb{\otimes})$ : day 6

(†): day 13

(घ): day 17

This article is protected by copyright. All rights reserved. 


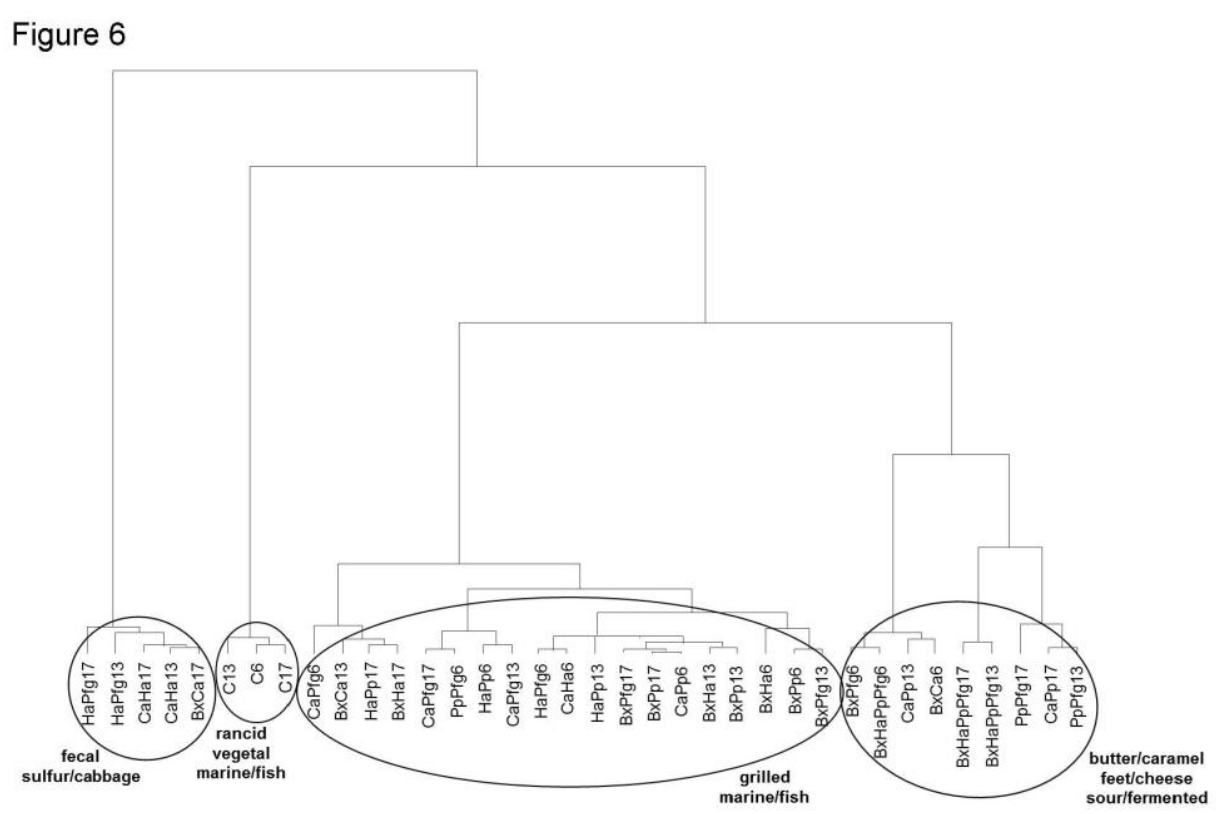

This article is protected by copyright. All rights reserved. 